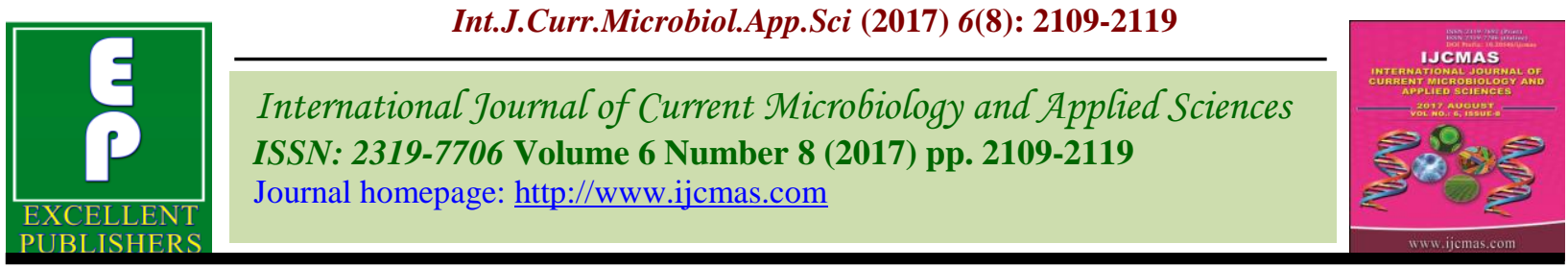

Original Research Article

https://doi.org/10.20546/ijcmas.2017.608.251

\title{
A Study on Colocasia as a Suitable Substrate for Production of Cellulase
}

\author{
Gayatree Jadeja $^{1}$ and Shilpi Verma ${ }^{2 *}$ \\ ${ }^{1}$ KVK Arnej, Anand Agriculture University, Gujarat, India \\ ${ }^{2}$ KVK Neemuch, RVSKVV, Gwalior, India \\ *Corresponding author
}

\section{A B S T R A C T}

\begin{tabular}{|c|}
\hline Keywords \\
\hline $\begin{array}{l}\text { Cellulase, Colocasia, } \\
\text { Cellulolytic fungi, } \\
\text { Cellulolytic } \\
\text { bacteria, Submerge } \\
\text { fermentation, } \\
\text { Cellulase biomass. }\end{array}$ \\
\hline Article Info \\
\hline $\begin{array}{l}\text { Accepted: } \\
\text { 19 June } 2017 \\
\text { Available Online: } \\
10 \text { August } 2017\end{array}$ \\
\hline
\end{tabular}

Keywords

Cellulase, Colocasia, Cellulolytic fungi, Cellulolytic bacteria, Submerge fermentation, Cellulase biomass.

\section{Introduction}

The major components of plant cell walls are cellulose, hemicellulose and lignin, with cellulose being the most abundant component (Saleem et al., 2008). Plant biomass comprises an average of $23 \%$ lignin, $40 \%$ cellulose and 33\% hemicellulose by dry weight (Ahmed et al., 2007).

Cellulose, a linear polymer of $d-$ anhydroglucopyranase units linked by $\beta-1,4-$ glucosidic bonds, with a degree of polymerization ranging from 15 to 10 , 00014000 , being the primary structural material of plant cell wall, is the most abundant carbohydrate in nature (Tuomela et al., 2000; Gardner et al., 1974). Cellulose is the principal constituent of the cell wall of most terrestrial plants. The source of cellulose is in plants and it is found as micro-fibrils $(2-20 \mathrm{~nm}$ in diameter and $100-40$, 000nm long). These form the structurally strong frame work in the cell walls (Omojasola et al., 2008).

Cellulase is an enzyme complex which breaks down cellulose to beta-glucose. Cellulase refers to a family of enzymes which act in concert to hydrolyze cellulose. Cellulase refers to a class of enzymes produced chiefly by fungi, bacteria, and protozoans that catalyze cellulolysis (i.e. the hydrolysis of cellulose). However, there are also cellulases produced by a few other types of organisms, such some termites and the microbial intestinal symbionts of other termites 
(Watanabe et al., 1998). Several different kinds of cellulases are known, which differ structurally and mechanistically (Sulzenbacher et al., 1997).

Cellulases are of substantial industrial interest. Researchers have strong interests in cellulases because of their applications in industries of starch processing, grain alcohol fermentation, malting, brewing and extraction of fruit and vegetable juices and pulp and paper industries (Sipos et al., 2010). In recent years, the interest in cell has increased due to many potential applications, for example, in the production of bio-energy and bio-fuel, in the textile industry and pulp and paper industry (Zhou et al., 2008). The most promising technology for conversion of lignocellulosic biomass to fuel ethanol is based on the enzymatic breakdown of cellulose using cellulose enzyme (Ali et al., 2009).

Cellulase were initially investigated several decades back for the bioconversion of biomass which gave way to research in the industrial applications of the enzymes in animal feed, food industry, with the shortage of fossile fuels and the arising need to find alternative source for renewable energy and fuels, there is a renewal of interest in the bioconversion of lignocellulosic biomass using celluloses and other enzymes. Colocasia is a genus of 25 or more species of flowering plants in the family Araceae, native to tropical polynesia and southeastern Asia. Its scientific name is colocasia esculenta. They are herbaceous perennial plants with a large rhizome on or just below the ground surface. The leaves are large to very large, $20-150 \mathrm{~cm}$ (7.9-59 in) long, with a sagittate shape. The elephant's-ear plant gets its name from the leaves, which are shaped like a large ear or shield (Wagner et al., 1999). In addition, the Colocasia has anti-cancer, Anti-inflammatory, Antioxidant / flavonoid glycosides effect (Biren, 2007).
The main object of present work is to utilize low cost substrate colocasia which is produced in large scale in this country and use for the production of cellulases.

\section{Materials and Methods}

\section{Isolation of cellulolytic bacteria and fungi}

Collect the sample of rotten wood from the yogi park near Greed, Anand. Isolate the bacteria on Nutreint Agar medium and fungi on Potato Dextrose Agar medium using Agar plate method (Jett et al., 1977). Study the morphology and cultural characteristics of bacteria and fungi by Gram staining, Motility test, Colony Characteristics.

\section{Screening of cellulolytic fungi for cellulose production}

The cellulolytic nature of fungi confirm first through the screening test. To this $1 \%$ of CMC was amended with Czepek-Dox agar media and the $\mathrm{pH}$ was adjust to 5. The media pour into sterile petri dishes, after solidification of media a small hole was made on the center of petri dishes aseptically and culture spore were added to this center. The plates were incubated for 3 days at $30^{\circ} \mathrm{C}$ and 2 days at $50^{\circ} \mathrm{C}$. After incubation the plates were stained with $1 \%$ congo red solution for 15 min, after that the congo red stain was neutralized with $1 \mathrm{M}$ Nacl solution. The yellow colour zone formation concern the ability of cellulose utilization and enzyme activity of fungal culture (Pradeep et al., 2011).

\section{Substrate}

The substrate colocasia collected from Kanjri near Anand.

\section{Preparation of substrate}

Leaves, Root, Stem of colocasia chopped into bits then oven dried slowly $50^{\circ} \mathrm{C}$ for 2 days. 
Pulverised into coarse particle size then used as substrate.

Preparation of fungal spore inoculums for cellulose production in liquid fermentation medium

Loopful of isolated fungi inoculated in the $100 \mathrm{ml}$ of Czepek-Dox Thom's liquid fermentation media. After inoculation incubate at $37^{\circ} \mathrm{C}$ for 48 hours.

\section{Preparation of cellulase production media}

Add 1\% substrate [Leaves, Root, Stem] in the marry mandel's mineral salt solution fermentation media and 5\% fungal inoculums from Czepek Dox Thom's liquid medium into Mary Mandel's mineral salt solution and incubate at $37^{\circ} \mathrm{c}$ temperature for $24,48,72$ hours. Mary Mandel's Mineral salts Solution (Jeffries, 1996).

\begin{tabular}{|l|l|l|l|l|l|l|}
\hline Composition & gm/lit & Control & Alkaline & $\begin{array}{l}\text { Alkaline + } \\
\text { Substrate }\end{array}$ & Acidic & $\begin{array}{l}\text { Acidic + } \\
\text { substrate }\end{array}$ \\
\hline $\begin{array}{l}\text { Substrate } \\
\text { (Root/Stem/Leaves) }\end{array}$ & $10 \mathrm{~g}$ & - & - & $\checkmark$ & - & $\checkmark$ \\
\hline Cellulose & $10 \mathrm{~g}$ & $\checkmark$ & $\checkmark$ & - & $\checkmark$ & - \\
\hline Peptone & $1 \mathrm{~g}$ & $\checkmark$ & $\checkmark$ & $\checkmark$ & $\checkmark$ & $\checkmark$ \\
\hline (NH4)2SO & $1.4 \mathrm{~g}$ & $\checkmark$ & $\checkmark$ & $\checkmark$ & $\checkmark$ & $\checkmark$ \\
\hline $\mathrm{KH} 2 \mathrm{PO} 4$ & $2 \mathrm{~g}$ & $\checkmark$ & $\checkmark$ & $\checkmark$ & $\checkmark$ & $\checkmark$ \\
\hline $\mathrm{CaCl2}$ & $0.3 \mathrm{~g}$ & $\checkmark$ & $\checkmark$ & $\checkmark$ & $\checkmark$ & $\checkmark$ \\
\hline $\mathrm{MgSO} 4.7 \mathrm{H} 20$ & $0.3 \mathrm{~g}$ & $\checkmark$ & $\checkmark$ & $\checkmark$ & $\checkmark$ & $\checkmark$ \\
\hline $\mathrm{Urea}$ & $0.3 \mathrm{~g}$ & $\checkmark$ & $\checkmark$ & $\checkmark$ & $\checkmark$ & $\checkmark$ \\
\hline $\mathrm{pH}$ & - & $\mathbf{7 . 5}$ & $\mathbf{9 . 5}$ & $\mathbf{9 . 5}$ & $\mathbf{3 . 5}$ & $\mathbf{3 . 5}$ \\
\hline
\end{tabular}

\section{Extraction of enzyme}

Sample withdrawn from the grown culture at 24, 48, 72 hours and then filter it using Whatman filter paper no 1 to remove solid then used for different assay.

Dry weight of cellulose biomass (Mary, 1974)

Dry in an oven an empty aluminum weighing pan or a sheet of cellulose acetate filter membrane, $47 \mathrm{~mm}$ in diameter, $0.45 \mu \mathrm{m}$ in pore size. Weigh them and store them in a desiccator lined with Drierite (anhydrous $\mathrm{CaSO}_{4}$ ). Stir the flask to suspend the culture evenly. Pour out $100 \mathrm{ml}$ of the culture into a graduated cylinder. Separate the cells from the broth either by centrifugation at $10,000 \mathrm{~g}$ for 5 minutes or by filtration. In the case of centrifugation, carefully discard the clear broth and scrape the cell paste from the centrifuge tube into a weighing pan. Rinse the centrifuge tube with a few $\mathrm{ml}$ of water. Pour the rinse water into the weighing pan, as well. In the case of filtration, the culture is poured into the holding reservoir fitted on the filter membrane. A vacuum is applied to pull the liquid through the membrane. Rinse the reservoir with a few $\mathrm{ml}$ of water and scrape any paste adhering to the glassware. The wet weight of the culture is measured immediately after all the water has been pulled through. Dry the cell paste in an oven set at $100^{\circ} \mathrm{C}$. The cells will be charred and the filter membrane will be burned if the temperature of the oven is set too high. Measure the weight of the pan/filter plus the cell paste periodically until 
there is no further decrease in the dry weight. It will take 6-24 hours to dry the sample completely, and the thickness of the paste. Calculate the difference in the weight, and express the dry weight in $\mathrm{g} / \mathrm{l}$.

\section{Carboxy methyl cellulose assay for} cellulose (Mandels et al., 1976)

\section{Endoglucanase assay}

Endoglucanase activity of fungal culture was quantified by carboxy methyl cellulose method. According to this method, $0.5 \mathrm{ml}$ of $1 \%$ carboxy methyl cellulose as a substrate was added to the $0.5 \mathrm{ml}$ of enzyme. This mixture was incubated at $50^{\circ} \mathrm{c}$ in a water bath for $30 \mathrm{~min}$. The reducing sugar produced in the reaction was estimated by DNS method. After incubation, $3 \mathrm{ml}$ of DNS reagent was added to each test tube and boiled for $5 \mathrm{~min}$ in a boiling waterbath. After boiling transfer to a cold water bath and added $10 \mathrm{ml}$ of distlled water. Mixed completely inverting the tube several time so that the solution separates from the bottom of the tubes at each inversion. The color developed in the test tubes was read at $540 \mathrm{~nm}$ in a spectrophotometer. The enzyme activity was expressed in terms of CMC units.CMC units were defined as the amount of enzyme releasing $\mathrm{IU} / \mathrm{ml}$ ( $\mu$ mole of reducing sugar from the substrate per minute per $\mathrm{ml}$ ).

\section{Glucose estimation (Miller, 1959)}

Enzyme removed from the fermentation media were assayed for total reducing sugars using DNSA method. The sample, control and glucose standards were prepare using the different aliquot of sample and standard in test tube and add $3 \mathrm{ml}$ DNS reagent. The mixture was boil for 5 minutes after that cool it and add $10 \mathrm{ml} \mathrm{d} / \mathrm{w}$ in each test tube then absorbance were read at $540 \mathrm{~nm}$ using a spectrophotometer, plot the standards on semilog paper (log percent $\mathrm{T}$ versus concentration).

\section{Protein estimation (Lowery et al., 1951)}

Protein content in culture filtrate was determined by Lowery's method. The culture was mixed with $0.1 \mathrm{ml} 2 \mathrm{~N} \mathrm{NaOH}$ and hydrolyzed for 10 minute at $100^{\circ} \mathrm{C}$ then treated with $1 \mathrm{ml}$ complex forming reagent (freshly prepared) incubated 10 minutes at room temperature then $0.5 \mathrm{ml}$ Folin-ciocalteau reagent was added. After 30 minutes of incubation in a dark place the colour developed was measured by spectrophotometer at $660 \mathrm{~nm}$.

\section{Ammonium sulphate precipitation}

It is very important to use fresh, desiccated ammonium sulfate. This ensures uniform and rapid dissolution. The day before use, place ammonium sulfate over night in ca. $120^{\circ} \mathrm{C}$ drying oven in a large beaker or drying dish (ammonium sulfate decomposes at $220^{\circ} \mathrm{C}$ ). Clean grinder carefully and grind dry ammonium sulphate to a fine powder. Wear a dust mask (if you don't need a mask, the powder is not dry enough).

Select the amount of ammonium sulphate powder from ammonium sulphate concentration table. Use ground powder immediately. Add the powder slowly but steadily with thorough mixing. Do not allow clumps to form. Allow precipitate to form for 30 minutes at $4^{\circ} \mathrm{C}$ with stirring. Recover precipitate by centrifugation. Solutions highly saturated in ammonium sulfate are quite dense and it can be difficult to pellet the precipitate. Remove supernatant, re spin briefly to clear remaining ammonium sulphate. Re-suspend pellets in a volume of buffer equal to the volume of the extract.

\section{SDS-PAGE gel electrophorsis}

It was carried out for determination of the protein contain of the highest cellulose producing media. 
Determination of optimal condition for cellulose production

A. Effect of varying Time:

Cellulase activity was measured at regular intervals like 24, 48, 72 hours.

B. Effect of varying $\mathrm{pH}$ :

The $\mathrm{pH}$ of the fermentation media were adjust to acidic (3.5), alkaline (9.5) and control (7.5) with $0.1 \mathrm{~N} \mathrm{HCl}$ or $0.1 \mathrm{~N} \mathrm{NaOH}$.

C. Effect of varying Temperature:

The fermentation was carried out at different temperature like $30^{\circ} \mathrm{C}, 35^{\circ} \mathrm{C}, 40^{\circ} \mathrm{C}, 45^{\circ} \mathrm{C}$ and $50^{\circ} \mathrm{C}$.

D. Effect of varying Substrate:

The fermentation was carried out using three different part of colocasia like Root, Stem, Leaf.

\section{Results and Discussion}

\section{Isolation of cellulolytic bacteria and fungi}

Prepared suspension with dilution and used for Spreading on Agar plate and Potato Dextrose agar medium. In Agar plate different type of bacterial colonies observed and in potato Dextrose Agar different type of fungal growth observed. Colony transferred From that bacterial colony and Fungal growth shows the isolated growth of bacteria on the Agar plate and fungi on potato Dextrose Agar.

\section{Screening of cellulolytic fungi using agar} plate method (zone method)

Three isolated strain of fungi was Screened for cellulose Enzyme Production. The formation of Yellow zone of hydrolysis shows its ability for cellulose Production.
From the $\mathrm{IF}_{1}, \mathrm{IF}_{2}, \mathrm{IF}_{3}$. From that Fungi $\mathrm{IF}_{2}$ shows maximum zone of hydrolysis which indicates CMC degradation as in figure 1 .

In prepared media inoculate the isolated strain of fungi. From the three isolated fungi. $\mathrm{IF}_{2}$ was used for the enzyme production because it shows Highest Enzyme activity.

\section{Carboxy methyl celluase assay for cellulose}

Table 1 shows the CMCase activity of colocasia leaf, Stem and Root at different temperature and different media on 24,48 and 72 hours incubation.

In Leaf substrate at 24,48 and 72 hours incubation the CMCase activity was found highest in $\mathrm{D}$ at $30^{\circ} \mathrm{C}, 35^{\circ} \mathrm{C}$ and $40^{\circ} \mathrm{C}$ and at $45^{\circ} \mathrm{c}, 50^{\circ} \mathrm{c}$ temperature the $\mathrm{C}$ Shows the highest CMCase activity. The lowest CMCase activity was found in control media at $30^{\circ} \mathrm{C}$, in the $\mathrm{A}$ media the CMCase activity was at $35^{\circ} \mathrm{C}, 45^{\circ} \mathrm{C}$ and $50^{\circ} \mathrm{C}$ as well as the $\mathrm{B}$ media shows the CMCase activity at $40^{\circ} \mathrm{C}$ Temperature. All the media A, B, C, D at different temperature shows the highly significant $(\mathrm{p}<0.01)$ and significant difference $(p<0.05)$ compared to the control media.

In Stem substrate at 24, 48 and 72 hours incubation the $\mathrm{CMC}$ activity was found highest in $\mathrm{D}$ at $35^{\circ} \mathrm{C}, 40^{\circ} \mathrm{C}, 45^{\circ} \mathrm{C}$ and $50^{\circ} \mathrm{C}$ and in $\mathrm{c}$ at $30^{\circ} \mathrm{c}$. The lowest $\mathrm{CMC}$ activity was found in control media at $30^{\circ} \mathrm{C}, 35^{\circ} \mathrm{C}$, $40^{\circ} \mathrm{C}, 45^{\circ} \mathrm{C}$ and $50^{\circ} \mathrm{C}$ All the media $\mathrm{A}, \mathrm{B}, \mathrm{C}$, $\mathrm{D}$ at different temperature shows the highly significant $(\mathrm{p}<0.01)$ and significant difference $(\mathrm{p}<0.05)$ compared to the control media. In Root Substrate at 24, 48 and 72 hours incubation the CMC activity was found highest in $\mathrm{D}$ at $30^{\circ} \mathrm{C}, 35^{\circ} \mathrm{C}, 50^{\circ} \mathrm{C}$. At $40^{\circ} \mathrm{C}$ and at $45^{\circ} \mathrm{C}$ temperature the $\mathrm{C}$ shows the highest CMC activity in Root substrate. The lowest CMC activity was found in control media at $50^{\circ} \mathrm{C}$, in the A media the CMC activity was at 
$45^{\circ} \mathrm{C}, 50^{\circ} \mathrm{C}$ as well as the $\mathrm{C}$ media shows the lowest $\mathrm{CMC}$ activity at $30^{\circ} \mathrm{C}, 35^{\circ} \mathrm{C}$ and $\mathrm{D}$ at $40^{\circ} \mathrm{c}$ Temperature. All the media A, B, C, D at different temperature shows the highly significant $(\mathrm{p}<0.01)$ and significant difference $(\mathrm{p}<0.05)$ compared to the control media.

In substrate Leaf in D media at $40^{\circ} \mathrm{c}$ temperature and 72 hours $(0.547 \mathrm{IU} / \mathrm{ml})$, in substrate Stem in D media at $50^{\circ} \mathrm{C}$ temperature and 48 hours $(0.830 \mathrm{IU} / \mathrm{ml})$, in substrate Root in D media at $50^{\circ} \mathrm{C}$ temperature and 48 hours $(2.719 \mathrm{IU} / \mathrm{ml})$ shows highest CMCase activity (Fig. 2).

\section{DNS method for glucose estimation}

Table 1 shows the glucose production of colocasia leaf, Stem and Root at different temperature and different media on 24, 48 and 72 hours incubation.

In Leaf substrate at 24, 48 and 72 hours incubation the Glucose production was found highest in $\mathrm{D}$ at $30^{\circ} \mathrm{C}, 35^{\circ} \mathrm{C}, 40^{\circ} \mathrm{C}$, the $\mathrm{C}$ shows the highest Glucose production at $45^{\circ} \mathrm{C}, 50^{\circ} \mathrm{C}$. The lowest Glucose production was found in control media at $30^{\circ} \mathrm{C}, 35^{\circ} \mathrm{C}, 45^{\circ} \mathrm{C}, 50^{\circ} \mathrm{C}$. In the $\mathrm{D}$ media the Glucose production was at $40^{\circ} \mathrm{C}$ shows the lowest Glucose production. All the media A, B, C, D at different temperature shows the highly significant $(p<0.01)$ and significant difference $(p<0.05)$ compared to the control media.

In Stem substrate at 24, 48 and 72 hours incubation the Glucose production was found highest in $\mathrm{D}$ at $35^{\circ} \mathrm{C}, 40^{\circ} \mathrm{C}, 45^{\circ} \mathrm{C}, 50^{\circ} \mathrm{C}$, the $\mathrm{C}$ Shows the highest Glucose production at $30^{\circ} \mathrm{C}$. The lowest Glucose production was found in control media at $35^{\circ} \mathrm{C}, 45^{\circ} \mathrm{C}, 50^{\circ} \mathrm{C}$. In the $\mathrm{A}$ media the Glucose production was at $30^{\circ} \mathrm{C}, \quad 40^{\circ} \mathrm{C}$ shows the lowest Glucose production. All the media $\mathrm{A}, \mathrm{B}, \mathrm{C}, \mathrm{D}$ at different temperature shows the highly significant $(\mathrm{p}<0.01)$ and significant difference $(\mathrm{p}<0.05)$ compared to the control media. In Root substrate at 24, 48 and 72 hours incubation the Glucose production was found highest in $\mathrm{D}$ at $30^{\circ} \mathrm{C}, 35^{\circ} \mathrm{C}, 50^{\circ} \mathrm{C}$, the $\mathrm{C}$ Shows the highest Glucose production at $45^{\circ} \mathrm{c}$ and A media at $40^{\circ} \mathrm{C}$. The lowest Glucose production was found in control media at $30^{\circ} \mathrm{C}, 35^{\circ} \mathrm{C}, 40^{\circ} \mathrm{C}, 45^{\circ} \mathrm{C}, 50^{\circ} \mathrm{C}$. All the media $\mathrm{A}, \mathrm{B}, \mathrm{C}, \mathrm{D}$ at different temperature shows the highly significant $(\mathrm{p}<0.01)$ and significant difference $(p<0.05)$ compared to the control media.

In substrate Leaf in D media at $50^{\circ} \mathrm{c}$ temperature and 48 hours $(1.945 \mathrm{mg} / \mathrm{ml})$, in substrate Stem in D media at $45^{\circ} \mathrm{C}$ temperature and 24 hours $(3.594 \mathrm{mg} / \mathrm{ml})$, in substrate Root in $\mathrm{D}$ media at $35^{\circ} \mathrm{C}$ temperature and 48 hours $(1.814 \mathrm{mg} / \mathrm{ml})$ shows highest Glucose production.

\section{Lowery method for protein estimation}

Table 1 shows the Protein secretion of colocasia Leaf Stem and Root at different temperature and different media on 24, 48 and 72 hours incubation.

In Leaf substrate at 24, 48 and 72 hours incubation the Protein secretion was found highest in $\mathrm{D}$ at $30^{\circ} \mathrm{C}, 35^{\circ} \mathrm{C}, 40^{\circ} \mathrm{C}, 45^{\circ} \mathrm{C}$, and $\mathrm{B}$ media at $50^{\circ} \mathrm{C}$ temperature. The lowest Protein secretion was found in Control media at $45^{\circ} \mathrm{C}, 50^{\circ} \mathrm{C}$. In the $\mathrm{A}$ media the Protein secretion was at $30^{\circ} \mathrm{C}, 35^{\circ} \mathrm{C}, 40^{\circ} \mathrm{C}$. All the media $\mathrm{A}, \mathrm{B}, \mathrm{C}, \mathrm{D}$ at different temperature shows the highly significant $(\mathrm{p}<0.01)$ and significant difference $(\mathrm{p}<0.05)$ compared to the control media.

In Stem substrate at 24, 48 and 72 hours incubation the Protein secretion was found highest in $\mathrm{D}$ at $30^{\circ} \mathrm{C}, 45^{\circ} \mathrm{C}$, and $\mathrm{B}$ media at $35^{\circ} \mathrm{C}, 40^{\circ} \mathrm{C}, 50^{\circ} \mathrm{C}$ temperature. The lowest Protein secretion was found in Control media at $45^{\circ} \mathrm{C}, 50^{\circ} \mathrm{C}$. In the $\mathrm{A}$ media the Protein 
secretion was at $30^{\circ} \mathrm{c}, 35^{\circ} \mathrm{c}, 40^{\circ} \mathrm{c}$. All the media A, B, C, D at different temperature shows the highly significant $(\mathrm{p}<0.01)$ and significant difference $(\mathrm{p}<0.05)$ compared to the control media. In Root substrate at 24, 48 and 72 hours incubation the Protein secretion was found highest in Control media at $30^{\circ} \mathrm{C}$, $35^{\circ} \mathrm{C}, 40^{\circ} \mathrm{C}, 45^{\circ} \mathrm{C}$ and $50^{\circ} \mathrm{C}$. The lowest Protein secretion was found in the $\mathrm{A}$ media the Protein secretion was at $30^{\circ} \mathrm{C}, 35^{\circ} \mathrm{C}, 45^{\circ} \mathrm{C}$ and $50^{\circ} \mathrm{C}$ and in $\mathrm{D}$ media at $30^{\circ} \mathrm{C}$. All the media A, B, C, D at different temperature shows the highly significant $(p<0.01)$ and significant difference $(p<0.05)$ compared to the control media. In substrate Leaf in D media at $35^{\circ} \mathrm{c}$ temperature and 72 hours (17.505 mg/ml), in substrate Stem in A media at $30^{\circ} \mathrm{c}$ temperature and 72 hours (17.057 $\mathrm{mg} / \mathrm{ml}$ ), in substrate Root in Control media at $30^{\circ} \mathrm{c}$ temperature and 48 hours $(8.047 \mathrm{mg} / \mathrm{ml})$ shows highest Protein secretion.

\section{Dry weight of cellulose biomass procedure from thesis}

Acidic + substrate showed highest activity at $40^{\circ} \mathrm{C}, 50^{\circ} \mathrm{C}$ at $24,48,72$ Hours. From the result of enzyme activity the acidic + Substrate media select for the Dry Weight of biomass. At $50^{\circ} \mathrm{C}$ the Leaf Substrate was incubate for 72 hours, Stem for 24 hours and Root for 48 hours in the Acidic + Substrate media (Table 1).

\section{Sodium dodecyl sulphate-polyacrylamide gel electrophoresis (SDS-PAGE)}

Molecular weight was determined by SDS gel as described in material and method used BSA as a marker. Molecular weight of BSA is 66, 000Da. Analysis of the enzyme by SDSPAGE were Shows the bands of three different sample of Acidic + Substrate media containing substrate Leaf, stem, Root (Figure $3)$.

Cellulose is the most abundant renewable natural resource in the world and a potential source for the production of industrial useful materials such as fuels and chemical. Cellulase is an enzyme complex which breaks down cellulose to beta-glucose. Cellulases are of substantial industrial interest. Researchers have strong interests in cellulases because of their applications in industries of starch processing, grain alcohol fermentation, malting, brewing and extraction of fruit and vegetable juices and pulp and paper industries.

Cellulolytic fungi can use cellulose as a primary carbone source. Pure cellulose such as cotton and avicel are good cellulase inducers, but expensive and non economical, consequently the use of less expensive substrates can decrease the production cost taro is an important staple food crop grown throughout many pacific Island countries part of Africa, Asia and the Caribbean for its freshly corm and its nutritious leaves. Taro corm is excellent source of carbohydrate and low in fat and protein whereas taro leaves contain higher source of protein and are also excellent source of carotene, Potassium, calcium, phosphorus, iron, riboflavin, thiamin, niacin, vitamin $\mathrm{A}$, vitamin $\mathrm{C}$ and dietary. Taro is the one of the few major staple food where both the leaf and underground parts are important in human diet as well as very economical compared to the other foods. So in the present study the attempt was to use colocasia as substrate for cellulase production. The Present study was planned to fulfill the objectives like Isolate the cellulolytic bacteria and fungi. 
Table.1 Dry weight of cellulase biomass $(\mathrm{gm} / 100 \mathrm{ml})$ of acidic + substrate media with different substarate

\begin{tabular}{|c|c|c|}
\hline Sr. No & Sample & Temperature $\left(50^{\circ} \mathrm{C}\right)$ \\
\hline \multicolumn{3}{|c|}{24 HOURS } \\
\hline 1 & LEAF & $5.1 \mathrm{gm}$ \\
\hline 2 & STEM & $4.5 \mathrm{gm}$ \\
\hline 3 & ROOT & $3.1 \mathrm{gm}$ \\
\hline \multicolumn{3}{|c|}{48 HOURS } \\
\hline 1 & LEAF & $7.4 \mathrm{gm}$ \\
\hline 2 & STEM & $4.2 \mathrm{gm}$ \\
\hline 3 & ROOT & $3.8 \mathrm{gm}$ \\
\hline \multicolumn{3}{|c|}{72 HOURS } \\
\hline$\overline{1}$ & $\overline{\text { LEAF }}$ & $8.8 \mathrm{gm}$ \\
\hline 2 & STEM & $3.6 \mathrm{gm}$ \\
\hline 3 & ROOT & $1.4 \mathrm{gm}$ \\
\hline
\end{tabular}

Fig.1 Isolation and screening of cellulolytic fungi

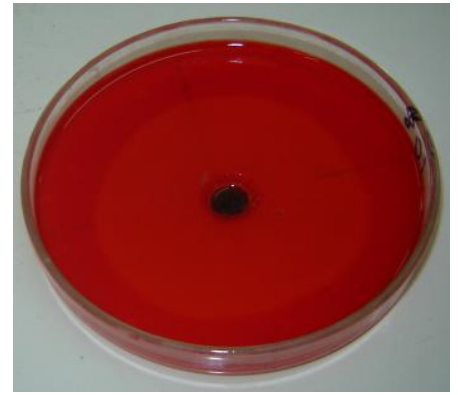

Zone of hydrolysis

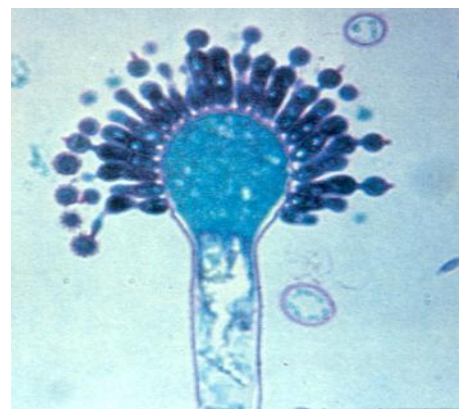

Isolated fungi $\mathrm{IF}_{2}$

Fig.2 CMCase activity of colocasia substrate at different temperature, time and media

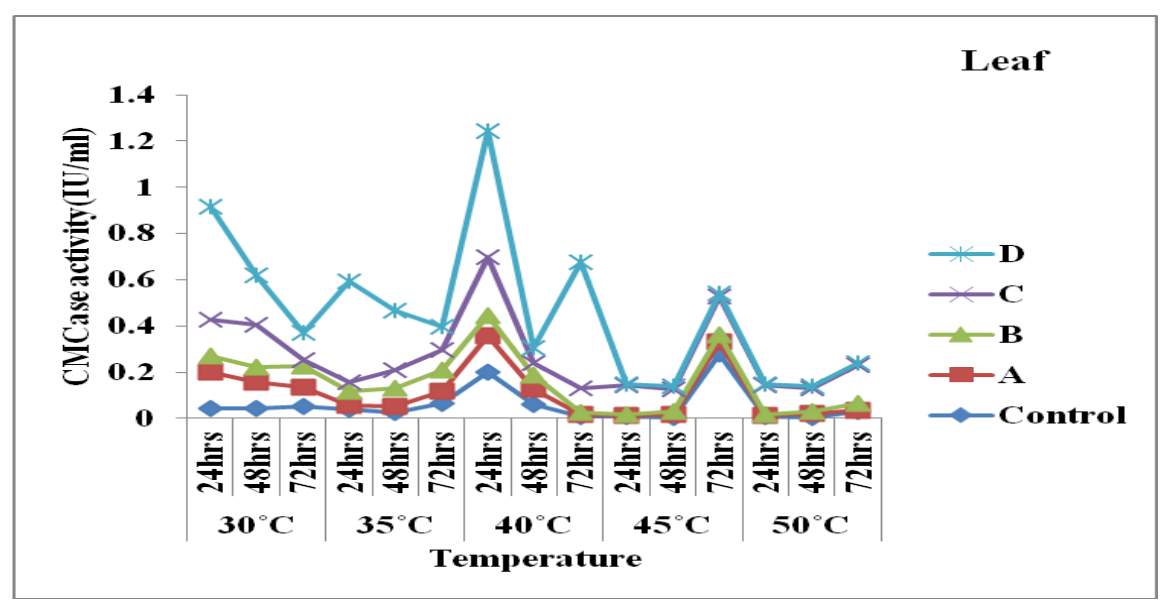



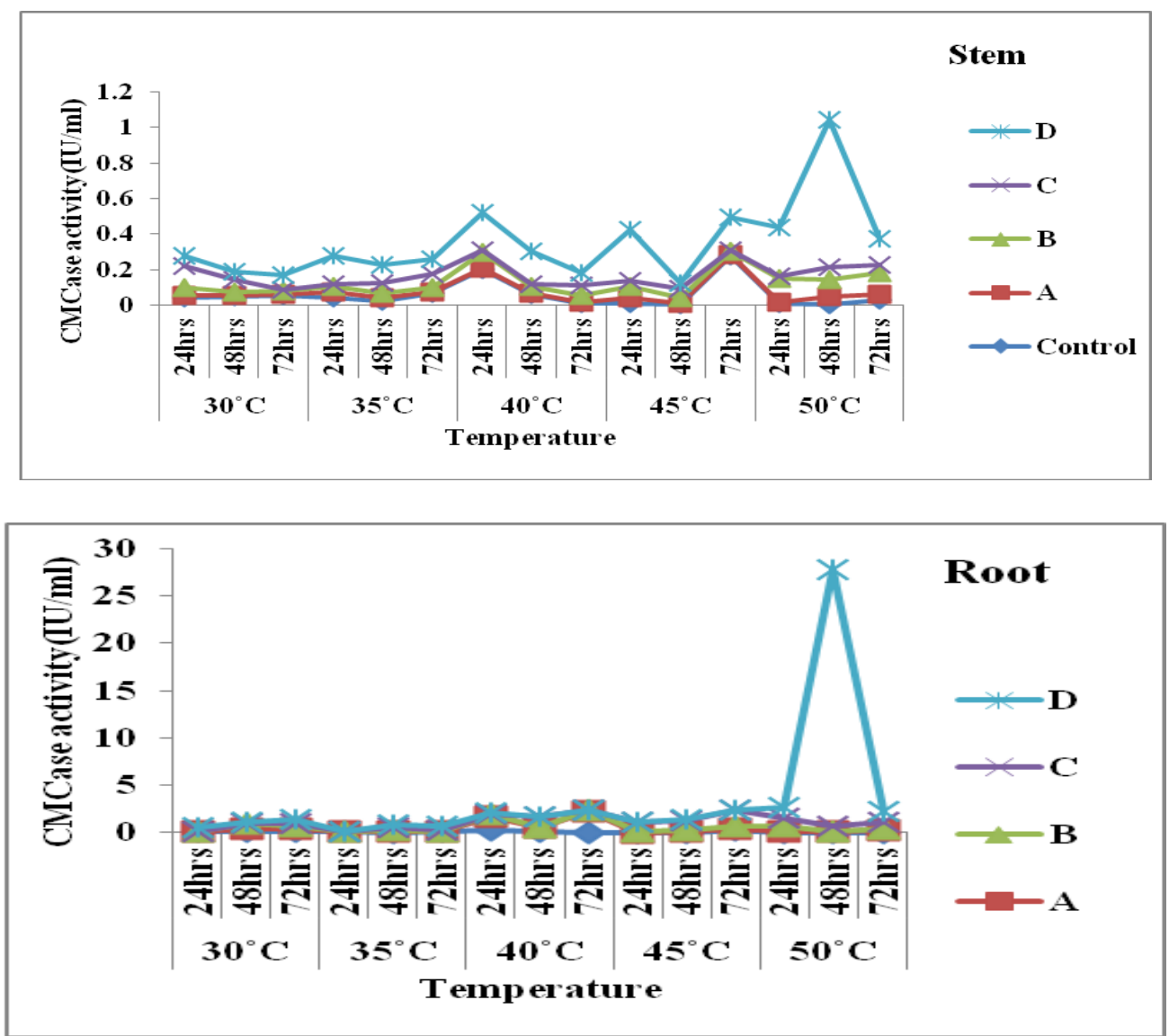

Control - Without substrate media A -Alkaline media,

B -Alkaline + Substrate media, $\quad$ C-Acidic media,

D - Acidic + Substrate media

Fig.3 Sodium dodecyl sulphate-polyacrylamide gel electrophoresis (SDS-PAGE) II I

Marker

M: Maker(Bovine serum albumin),

II: Acidic+Substrate(Root),
I: Acidic+Substrate(Leaf)

III: Acidic+Substrate(Stem) 
To Determine the cellulase production from the colocasia substrate using the isolated cellulolytic fungi, to determine the optimal condition for the cellulase production condition such as Temperature $\left(30^{\circ} \mathrm{c}, 35^{\circ} \mathrm{c}\right.$, $40^{\circ} \mathrm{c}, 45^{\circ} \mathrm{c}, 50^{\circ} \mathrm{c}$ ), $\mathrm{pH}$ (Alkaline and Acidic), Time (24, 48, $72 \mathrm{hrs)}$ ) and substrate (Colocasia Leaf, Root, Stem) and estimate CMCase activity by Mandeles and Andreoti, reducing sugar by DNS method and protein by Lowry method. Determine the dry weight of cellulase biomass Measurement of molecular weight of the sample which contains highest cellulase production was also performed using SDS PAGE gel electrophoresis. Three bacterial i.e. IB1, IB2 and IB3 strains as well as three fungal i.e. IF1, IF2 and IF3 was isolated from the rotten wood.

In next phase of these studies the isolated fungi and bacteria Strain were screened out using zone method. The IF3 fungal strain was selected for further production of cellulase. The cellulase production using different liquid media i.e. Control, Alkaline, Alkaline + Substrate, Acidic, Acidic + Substrate and the submerge fermentation was done. After that was used for the assessment of cellulase production in phase IV. The different time 24 , 48 , and72 hours incubation at different temperature i.e. $30^{\circ} \mathrm{C}, 35^{\circ} \mathrm{C}, 40^{\circ} \mathrm{C}, 45^{\circ} \mathrm{C}$, $50^{\circ} \mathrm{C}$ for all the three substrate like colocasia leaf, stem and root were used for the CMCase essay, Reducing Sugar essay and Protein essay.

In conclusion, this study revealed that colocasia leaf, stem and root which are very economic as well as produce large amount of cellulase enzyme when hydrolyzed by cellulytic fungi in acidic $\mathrm{pH}$. The suitable conditions for cellulase production are $50^{\circ} \mathrm{C}$ temperature and $24 \mathrm{hrs}, 48 \mathrm{hrs}$ and $72 \mathrm{hrs}$ are suitable for stem $(0.830 \mathrm{IU} / \mathrm{ml})$, root $(2.719$ $\mathrm{IU} / \mathrm{ml})$ and leaf $(0.547 \mathrm{IU} / \mathrm{ml})$, respectively. So instead of being left behind for natural degradation can be utilized effectively under these conditions, to produce cellulase.

For the further research aspect the cellulase production can be measured using bacterial strain as well as by changing the composition of the media preparation.

\section{References}

Ahmed, S., Jabeen, A., Jamil, A. 2007. Xylanase From Trichoderma Harzianum: Enzyme Characterization And Gene Isolation. J. Chem. Soc. Pak., 29: 176-182.

Ali, S., Ahmed, S., Sheikh, Ma, Hashmi, As, Rajoka, Mi, Jamil, A. 2009. Lysine Production By L-Homoserine Resistant Mutant Of Brevibacterium flavum. $J$. Chem. Soc. Pak., 31: 97-102.

Biren, N., Shah. 2007. The anti-inflammatory activity of the leaves of Colocasia esculenta. Saudi Pharmaceutical J., 15: 3-4.

Gardner, K.H. And J. Blackwell. 1974. The Structure Of Native Cellulose. Biopolymers, 13: 1975- 2001.

Jeffries, T.W. 1996. Production and Applications of Cellulase Laboratory Procedures, 1-10.

Jett, B.D., Hatter, K.L., Huycke, M.M., and Gilmore, M.S. 1997. Simplified agar plate method for quantifying viable bacteria. BioTechniques, 23: 648-650.

Lillie, R.D. 1977. The Gram Stain: A quick method for staining gram positive organisms in tissue. Arch. Path., 5: 828834.

Lowery, O.H., Rosebrough N.J., Farr A.L. and Randall R.J. 1951. Protein Measurement With The Folin Phenol Reagent. J. Biol. Chem., 193: 265-275.

Mandels, M. and Andreoti, R.C. 1976. Measurement Of Saccharifying Cellulase. Biotechnol. Bioeng. Symp., 6: 21-23. 
Mary Mandels. 1974. Production and Applications of Cellulase. Laboratory Procedures Handbook.

Miller, G.L. 1959. Use Of Dinitrosalicyclic Acid Reagent For Determination Of Reducing Sugar. Anal. Chem., 31: 426428.

Omojasola, P. Folakemi, Jilani, Omowumi Priscilla And Ibiyemi, S.A. 2008. Cellulase Production By Some Fungi Cultured On Pineapple Waste. Nature and Sci., 6(2).

Pradeep, M., Reddy and Narasimha, G. 2011. Utilization Of Pea Seed Husk As A Substrate For Cellulase Production By Mutant Aspergillus Niger. Insight Biotechnol., 1 (2).

Saleem, F., Ahmed, S., Jamil, A. 2008. Isolation of a xylan degrading gene from genomic DNA library of a thermophilic fungus Chaetomium thermophile ATCC 28076. Pak. J. Bot., 40: 1225-1230.

Sipos, B., Benko, Z., Dienes, D., Réczey, K., Viikari, L., Siika-Aho, M. 2010. Characterisation of Specific Activities And Hydrolytic Properties of CellwallDegrading Enzymes Produced By Trichoderma Reesei Rut C30 On
Different Carbon Sources. Appl. Biochem. Biotechnol., 161(1-8): 161: 347-64.

Sulzenbacher, G., Shareck, F., Morosoli, R., Dupont, C., and Davies, G. 1997. "The Streptomyces Lividans Family 12 Endoglucanase: Construction of The Catalytic Cre, Expression, and X-Ray Structure At $1.75 \AA$ Resolution". Biochem., 36: 16032-16039.

Tuomela, M., M. Vikman, A. Hatakka, M. Itavaara. 2000. Biodegradation Of Lignin In A Compost Environment. Biores. Technol., 72: 169-183.

Wagner, W.L., D.R. Herbst, and S.H. Sohmer 1999. Manual Of The Flowering Plants Of Hawai'I, Bishop Museum Press.1357.

Watanabe, H., Hiroaki Noda, Tokuda, G., Lo, N. 1998. Role of The Termite Gut Macrobiota In Symbiotic Digestion, Biology Of Termites: A Modern Synthesis, 2010: Ch. 16.

Zhou, J., Wang, Yh, Chu, J., Zhuang, Yp, Zhang, Sl, Yin, P. 2008. Identification And Purification of the main components of cellulases from a mutant strain of Trichoderma viride T 100-14. Biores. Technol., 99: 6826-6833.

\section{How to cite this article:}

Gayatree Jadeja and Shilpi Verma. 2017. A Study on Colocasia as a Suitable Substrate for Production of Cellulase. Int.J.Curr.Microbiol.App.Sci. 6(8): 2109-2119.

doi: https://doi.org/10.20546/ijcmas.2017.608.251 